\title{
Risk Factors for Complications in Acute Appendicitis among Paediatric Population
}

\author{
Rajesh Poudel, 'Tika Ram Bhandari ${ }^{1}$ \\ 'Department of Surgery, Universal College of Medical Sciences, Bhairahawa, Nepal.
}

\section{ABSTRACT}

Introduction: Appendicitis is one of the most common causes of acute abdomen in children. Patients who are diagnosed early and undergo an appendectomy before perforation have a good outcome. However, it is difficult to diagnose in young children because its clinical manifestations may be atypical. The aim of this study was to determine the risk factors for complications in acute appendicitis in paediatric population.

Methods: We performed a cross sectional study on children (age $\leq 18$ years) who underwent appendectomy for suspected appendicitis from January 2014 to December 2015. Medical records of patients who met inclusion criteria were reviewed. Preoperative, operative and post-operative data were analyzed. The main outcome measure was intraoperative confirmation of gangrenous or perforated appendicitis. Multivariate logistic regression analysis was performed, and the main predictors of interest were patient's age, duration of pain and total leucocyte count.

Results: Total 73 paediatric patients (46 males) with mean age $13 \pm 3.8$ were studied. In multivariate logistic regression analysis, patients having pain duration more than 72 hours and patients with leucocyte count $>15000 / \mathrm{mm}^{3}$ were more likely to have complicated appendicitis [(OR:14.6), (95\% CI= 2.40 - 89.77), $(\mathrm{P}=0.004)]$ and $[(\mathrm{OR}=16.38),(95 \% \mathrm{CI}=1.836-146),(\mathrm{P}=0.012)]$ respectively. However, the age of the patient is not independently associated with complicated appendicitis.

Conclusions: Increase in total leucocyte count and duration of the presentation can be a good marker of complicated appendicitis.

Keywords: appendicitis; complicated; gangrenous; pediatric; perforated; risk factors.

\section{INTRODUCTION}

Appendicitis is one of the most common causes of acute abdomen in children. ${ }^{1-3}$ Patients who are diagnosed early and undergo an appendectomy before perforation have

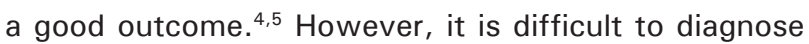
in young children because its clinical manifestations may be atypical. ${ }^{6-8}$ Children tend to have higher rates of appendiceal perforation than do adults. ${ }^{9-11}$

Several factors may contribute to this observation.
First, children may present with a variety of atypical symptoms, in contrast with the classic periumbilical pain that later migrates to the right lower quadrant. In addition, very young children may have little omentum and intraabdominal fat, allowing peritoneal spread to occur more readily. ${ }^{7,12}$ Finally, children tend to present

Correspondence: Dr. Rajesh Poudel, Department of Surgery Universal College of Medical Sciences, Bhairawha, Nepal. Email: rajeshpoudel@yahoo.com, Phone: +9779841606276. 
later than adults, thereby causing a delay in diagnosis that contributes to a higher perforation rate. ${ }^{12}$

The aim of this study was to determine the risk factors for complications in acute appendicitis in the paediatric population.

\section{METHODS}

We performed a cross sectional study. The ethical approval was taken from Institutional Review Board at Universal College of Medical Sciences (UCMS), Bhairahawa. Medical records of all children lage $\leq 18$ years) who underwent appendectomy for suspected appendicitis from January 2014 to December 2015 at UCMS, Bhairahawa were reviewed. Those patients with appendicular lump, interval appendectomy, and negative appendectomy were excluded.

Variables analyzed were patient age, sex, duration of pain, admission vitals and total leucocyte count. Primary outcome measure was intraoperative findings of complicated appendicitis. Complicated appendicitis was defined as the intraoperative identification of perforated or gangrenous appendicitis. Perforated appendicitis was defined as the presence of an appendiceal luminal disruption, visible hole in the appendix, or evidence of a fecalith outside the appendix, whereas gangrenous appendicitis was defined as the presence of gray or black discoloration of the appendiceal wall in the absence of perforation. ${ }^{13}$ According to intraoperative findings patients were divided into two groups, complicated appendicitis and non-complicated appendicitis. Secondary outcome measures were duration of surgery, length of hospital stay and wound infection between two groups.

Statistical analyses were conducted using Statistical Package for the Social Sciences (SPSS) version 23. Descriptive statics were calculated for all variables. A Multivariate logistic regression analysis was performed to identify independent predictors of complicated appendicitis. Bivariate analysis was performed to determine the association between complicated appendicitis and duration of surgery, length of hospital stay and wound infection. A categorical variable was compared with Chi Square or Fisher exact test and continuous variables were compared with independent samples T-test and Mann-Whitney $U$ test, where appropriate. $\mathrm{P}$ value less than 0.05 was considered significant.

\section{RESULTS}

During this two year study period, a total of 73 patients met inclusion criteria. A total of $46(63.01 \%)$ were male and $27(36.98 \%)$ were female with mean age of $13 \pm 3.8$ were studied. The median duration of presentation after the onset of pain was $48 \pm 39$ hours ranging from 2 to 192 hours. Complicated appendicitis was found in 27 patients $(37 \%)$. There were no significant differences between patients with complicated appendicitis and non-complicated appendicitis with regard to age, sex or admission vitals except for the duration of pain in hours and white blood cell count (Table 1).

\begin{tabular}{|c|c|c|c|}
\hline Variable & $\begin{array}{l}\text { Complicated } \\
\text { appendicitis }\end{array}$ & $\begin{array}{l}\text { Non } \\
\text { complicated } \\
\text { appendicitis }\end{array}$ & $\begin{array}{l}\mathrm{P} \\
\text { Value }\end{array}$ \\
\hline Age & $12 \pm 4.8$ & $13.46 \pm 18$ & 0.86 \\
\hline Male Sex & 17 & 29 & 0.99 \\
\hline $\begin{array}{l}\text { Duration of } \\
\text { pain in hours }\end{array}$ & $75 \pm 43$ & $39 \pm 29$ & 0.01 \\
\hline $\begin{array}{l}\text { Temperature, } \\
{ }^{\circ} \mathrm{F}\end{array}$ & $98 \pm 1.05$ & $98 \pm 1.2$ & 0.08 \\
\hline $\begin{array}{l}\text { Heart Rate, } \\
\text { bpm }\end{array}$ & $97.93 \pm 22$ & $89 \pm 14$ & 0.18 \\
\hline Systolic BP & $103 \pm 13$ & $107 \pm 10$ & 0.16 \\
\hline $\begin{array}{l}\text { Respiratory } \\
\text { rate }\end{array}$ & $22 \pm 6$ & $21 \pm 7$ & 0.57 \\
\hline $\begin{array}{l}\text { WBC count (/ } \\
\left.\mathrm{mm}^{3}\right) \\
\text { bpm = beats } \\
=\text { white blood }\end{array}$ & $\begin{array}{l}13800 \pm 5000 \\
\text { per minute; } B P \\
\text { cell, } \mathrm{mm}=\mathrm{mil}\end{array}$ & $\begin{aligned} & 11900 \pm 4200 \\
&= \text { blood pressur } \\
& \text { llimeter. }\end{aligned}$ & $\begin{array}{l}0.04 \\
e ; W B C\end{array}$ \\
\hline
\end{tabular}

Multivariate logistic regression analysis was performed to identify independent predictors for complicated appendicitis. The increase in duration of pain was associated with higher odds of complicated appendicitis. Compared to pain duration less than 24 hours, patients having pain duration more than 72 hours were more likely to have complicated appendicitis (Odds ratio = 14.6, 95\% Confidence interval $2.40-89.77, \mathrm{P}=$ .004). Compared to Total Leucocyte count less than 11000, Patient with Leucocyte count $>15000$ had higher odds of having complicated appendicitis (Odds ratio $=16.38,95 \% \mathrm{Cl} 1.836-146, \mathrm{P}=.012)$. However, the age of the patient is not independently associated with complicated appendicitis (Table 2).

\begin{tabular}{|c|c|c|c|}
\hline Variable & $\begin{array}{l}\text { Odd } \\
\text { ratio }\end{array}$ & $\begin{array}{l}95 \% \\
\text { confidence } \\
\text { interval }\end{array}$ & $P$ value \\
\hline \multicolumn{4}{|l|}{ Pain duration } \\
\hline $24 \mathrm{hrs}$ or less & Ref & & \\
\hline $25-48$ hrs & 1.52 & $.171-13.49$ & .70 \\
\hline 49- 72 hrs & 4.41 & $.668-29.11$ & .12 \\
\hline
\end{tabular}


Rajesh et al. Risk Factors for Complications in Acute Appendicitis among Paediatric Population

\begin{tabular}{|lccc|}
$\begin{array}{l}\text { More than } 72 \\
\text { hrs }\end{array}$ & 14.6 & $2.40-89.77$ & .004 \\
$\begin{array}{l}\text { Total } \\
\text { Leucocyte }\end{array}$ & & & \\
$<11000$ & Ref & & \\
$11000-15000$ & 4.287 & $.743-24.76$ & .104 \\
$>15000$ & 16.38 & $1.836-146$ & .012 \\
Age (Years) & & & \\
$2-6$ & Ref & & \\
$7-12$ & .195 & $.018-2.18$ & .185 \\
$13-18$ & 1.61 & $.142-18.31$ & .699 \\
hrs $=$ Hours; Ref $=$ Reference & \\
\hline
\end{tabular}

Bivariate analysis was done to compare the outcome of patients in two groups. There was a significant difference in the length of hospital stay among patients who had complicated appendicitis vs. non complicated appendicitis ( 6 vs 4 days, $p<0.001$ ). Similarly, there were significant differences in duration of surgery and surgical site infection in two groups $(p=0.03$ and $p=$ 0.007 respectively) (Table 3 ).

Table 3. Bivariate analysis for outcome in two groups.

\begin{tabular}{|llll|}
\hline Variable & $\begin{array}{l}\text { Complicated } \\
\text { appendicitis }\end{array}$ & $\begin{array}{l}\text { Non } \\
\text { complicated } \\
\text { appendicitis }\end{array}$ & P Value \\
$\begin{array}{l}\text { Duration } \\
\text { of surgery } \\
\text { (minutes) }\end{array}$ & $99 \pm 34.33$ & $73 \pm 25.6$ & 0.03 \\
$\begin{array}{l}\text { Length of } \\
\text { hospital stay } \\
\text { (days) }\end{array}$ & $6 \pm 2.66$ & $4 \pm 1.58$ & $<0.001$ \\
$\begin{array}{l}\text { Wound } \\
\text { infection }\end{array}$ & $7(25.9 \%)$ & $2(4.3 \%)$ & 0.007 \\
\hline
\end{tabular}

\section{DISCUSSION}

In this cross sectional study we found that duration of presentation after onset of pain and total leucocyte count were independently associated with complicated appendicitis. And patient with complicated appendicitis were likely to have more surgical site infection and increased length of hospital stay.

The approach to the diagnosis of acute appendicitis is mainly clinical. Diagnosis of acute appendicitis in children may be difficult especially in those having atypical symptoms and signs. Delay in diagnosis may lead to complicated appendicitis with an increase in morbidity and mortality. Duration of symptoms may be a factor in the high perforation rate seen in very young children, as signs and symptoms may be less specific.7,14 However, other factors, such as the lack of a well-developed omentum, may also contribute to the rapid progression of complicated appendicitis in children. Although it is generally understood that appendicitis in very young children behaves differently, the exact age cutoff is less clear.

Several studies have been done to identify predictors for complications in acute appendicitis. In a study done by Mahavir Singh et al. in India, where they analyze 102 cases and found that complicated appendicitis was associated with a delay in presentation $>72$ hours and children less than age 5 were more likely to have complications. ${ }^{14}$

Another study done Chaitan K. Narsule et al. where they analyzed 202 patients and found that the perforation rate rose in a linear fashion from $10 \%$ by 18 hours to $44 \%$ by 36 hours. If symptoms were present for more than 2 days, the risk of perforation was greater than $40 \%$. They found no difference in white cell counts in two groups; in contrast, our study shows that white cell counts were significantly higher in patient with complicated appendicitis group. ${ }^{15}$

Likewise, another study done by William Bonadio et al. in New York, where they conducted a retrospective case review of 248 consecutive children aged less than 18 years. They found that the risk for developing perforation increased by 1.10 for each hour of time delay from emergency department presentation to surgery; the estimated odds ratios for developing perforation per interval of in-hospital delay were 2.05 at 8 hours, 4.22 at 16 hours, 8.67 at 24 hours. They also further concluded that antibiotic therapy does not reliably prevent the progression of the disease. This could perhaps be due to the predominant effect of ischemia (rather than bacterial infection) causing progression of tissue compromise, especially in those with the solid concretion of an appendicolith. ${ }^{16}$

We also analyzed the postoperative outcomes in patients with complicated appendicitis in means of length of hospital stay and surgical site infection. There was a significant difference in hospital stay as well as surgical site infection. Most studies done for analyzing the risk factors for perforations have agreed with its association with duration of pain. In addition to duration of presentation, our studies showed that increase in total leucocyte count is also associated with complicated appendicitis.

There are several limitations to this study. Because of its retrospective design, there are potential for bias in data gathering. Since the study population was from a single medical center, the results may be less generalizable than those from multicenter studies. There 
were no clear data regarding the use of preoperative antibiotics. Whether the use of preoperative antibiotics has any meaningful impact on preventing complications is unclear but may be an area for future research.

\section{CONCLUSIONS}

In conclusion, increase in leucocyte count and duration of presentation can be good predictors of complicated appendicitis. Patients with complicated appendicitis have prolonged hospital stay and a higher incidence of wound infection. There should be a higher index of suspicion of complicated appendicitis in patient with late presentation and high leucocyte count.

\section{Conflict of Interest: None.}

\section{REFERENCES}

1. Aarabi S, Sidhwa F, Riehle KJ, Chen Q, Mooney DP. Paediatricappendicitis in New England: epidemiology and outcomes. J Pediatr Surg. 2011 Jun;46(6):1106-14. [PubMed]

2. Scholer SJ, Pituch K, Orr DP, Dittus RS. Clinical outcomes of children with acute abdominal pain. Pediatrics. 1996;98(4 Pt 1):680-5. [PubMed]

3. Anderson JE, Bickler SW, Chang DC, Talamini MA. Examining a common disease with unknown etiology: trends in epidemiology and surgical management of appendicitis in California, 1995-2009. World J Surg. 2012 Dec;36(12):2787-94. [PubMed]

4. Yardeni D, Hirschl RB, Drongowski RA, Teitelbaum DH, Geiger JD, Coran AG. Delayed versus immediate surgery in acute appendicitis: do we need to operate during the night? J Pediatr Surg. 2004 Mar;39(3):464-9. [ㄹuMed]

5. Warner BW, Kulick RM, Stoops MM, Mehta S, Stephan M, Kotagal UR. An evidenced-based clinical pathway for acute appendicitis decreases hospital duration and cost. J Pediatr Surg. 1998 Sep;33(9):1371-5. [ubMed]

6. Rothrock SG, Skeoch G, Rush JJ, Johnson NE. Clinical features of misdiagnosed appendicitis in children. Ann Emerg Med. 1991 Jan;20(1):45-50. [PubMed]

7. Nance ML, Adamson WT, Hedrick HL. Appendicitis in the young child: a continuing diagnostic challenge. Pediatr Emerg Care. 2000 Jun;16(3):160-2. [PubMed]

8. Colvin JM, Bachur R, Kharbanda A. The presentation of appendicitis in preadolescent children. Pediatr Emerg Care. 2007 Dec;23(12):849-55. [PubMed]
9. Livingston EH, Woodward WA, Sarosi GA, Haley RW. Disconnect between incidence of nonperforated and perforated appendicitis: implications for pathophysiology and management. Ann Surg. 2007 Jun; 245(6): 886-92. [MC]

10. Körner H, Söndenaa K, Söreide JA, Andersen E, Nysted A, Lende $\mathrm{TH}$, Kjellevold $\mathrm{KH}$. ncidence of acute nonperforated and perforated appendicitis: age-specific and sex-specific analysis. World J Surg. 1997 Mar-Apr;21(3):313-7. [PubMed]

11. Lee SL, Ho HS. Acute appendicitis: is there a difference between children and adults? Am Surg. 2006 May;72(5):409-13. [PubMed]

12. Mallick MS. Appendicitis in pre-school children: a continuing clinical challenge. A retrospective study. Int J Surg. 2008 Oct;6(5):371-3. [PubMed]

13. Kim DY, Nassiri N, Saltzman DJ, Ferebee MP, Macqueen IT, Hamilton C, et al. Postoperative antibiotics are not associated with decreased wound complications among patients undergoing appendectomy for complicated appendicitis. Am J Surg. 2015 Dec;210(6):983-7. [PubMed]

14. Singh M, Kadian YS, Rattan KN, Jangra B. Complicated appendicitis: analysis of risk factors in children. Afr J Paediatr Surg. 2014 Apr-Jun;11(2):109-13. [PubMed]

15. Narsule CK, Kahle EJ, Kim DS, Anderson AC, Luks FI. Effect of delay in presentation on rate of perforation in children with appendicitis. Am J Emerg Med. 2011 Oct;29(8):890-3. [PubMed]

16. Bonadio W, Brazg J, Telt N, Pe M, Doss F, Dancy L, et al. Impact of In-Hospital Timing to Appendectomy on Perforation Rates in Children with Appendicitis. J Emerg Med. 2015 Nov;49(5):597-604. [PubMed] 